\title{
Refuge
}

Canada's Journal on Refugees

revue canadienne sur les réfugiés

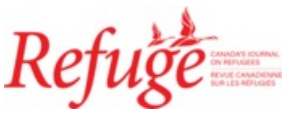

\section{“A Legacy of Confusion”: An Exploratory Study of Service Provision under the Reinstated Interim Federal Health Program}

\author{
Y.Y. Brandon Chen, Vanessa Gruben et Jamie Chai Yun Liew
}

Volume 34, numéro 2, 2018

URI : https://id.erudit.org/iderudit/1055580ar

DOI : https://doi.org/10.7202/1055580ar

Aller au sommaire du numéro

Éditeur(s)

Centre for Refugee Studies, York University

ISSN

0229-5113 (imprimé)

1920-7336 (numérique)

Découvrir la revue

Citer cet article

Chen, Y., Gruben, V. \& Liew, J. (2018). “A Legacy of Confusion”: An Exploratory Study of Service Provision under the Reinstated Interim Federal Health

Program. Refuge, 34(2), 94-102. https://doi.org/10.7202/1055580ar
Résumé de l'article

Après des années de réductions budgétaires, le programme canadien de soins de santé aux réfugiés, ou Programme fédéral de santé intérimaire (PFSI), a été pleinement réha-bilité en 2016. Dans cette étude exploratoire ont été menés onze entretiens qualitatifs semi-structurés avec des fournisseurs de services aux réfugiés de la Ville d'Ottawa pour ensavoir plus sur l'expérience qu'ils ont à ce jour du PFSI réhabilité. De ces entretiens se sont dégagés cinq thèmes : les défis en matière de fourniture de services au cours des années de réductions budgétaires du PFSI, l'appui à la réhabilitation du PFSI, les lacunes de statut dans le PFSI actuel, la confusion actuelle concernant le PFSI, et les obstacles administratifs décourageant les professionnels de la santé de participer au PFSI. Des travaux de recherche sont encore nécessaires pour établir si les défis qui accompagnent la réhabilitation du PFSI se situent à l'échelle nationale.
Copyright (c) Refuge: Canada's Journal on Refugees, 2018

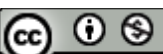

Ce document est protégé par la loi sur le droit d'auteur. L'utilisation des services d'Érudit (y compris la reproduction) est assujettie à sa politique d'utilisation que vous pouvez consulter en ligne. 


\title{
"A Legacy of Confusion": An Exploratory Study of Service Provision under the Reinstated Interim Federal Health Program
}

\author{
Y.Y. BRANDON CHEN, VANESSA GRUBEN, AND JAMIE CHAI YUN LIEW ${ }^{1}$
}

\section{Abstract}

After years of cuts, Canada's refugee health-care program, the Interim Federal Health Program (IFHP), was fully restored in 2016. In this exploratory study, eleven semi-structured qualitative interviews were conducted with refugee service providers in the City of Ottawa to learn about their experience with the restored IFHP to date. Five themes emerged from the interviews: service provision challenges during the years of IFHP cuts; support for IFHP restoration; entitlement gaps in the current IFHP; ongoing confusion about the IFHP; and administrative barriers deterring health professionals from IFHP participation. More research is needed to determine whether the identified challenges with the reinstated IFHP arise on a national scale.

\section{Résumé}

Après des années de réductions budgétaires, le programme canadien de soins de santé aux réfugiés, ou Programme fédéral de santé intérimaire (PFSI), a été pleinement réhabilité en 2016. Dans cette étude exploratoire ont été menés onze entretiens qualitatifs semi-structurés avec des fournisseurs de services aux réfugiés de la Ville d'Ottawa pour en savoir plus sur l'expérience qu'ils ont à ce jour du PFSI réhabilité. De ces entretiens se sont dégagés cinq thèmes: les défis en matière de fourniture de services au cours des années de réductions budgétaires du PFSI, lappui à la réhabilitation du PFSI, les lacunes de statut dans le PFSI actuel, la confusion actuelle concernant le PFSI, et les obstacles administratifs décourageant les professionnels de la santé de participer au PFSI. Des travaux de recherche sont encore nécessaires pour établir si les défis qui accompagnent la réhabilitation du PFSI se situent à l'échelle nationale.

\section{Introduction}

A legacy of confusion plagues the Interim Federal Health Program (IFHP), Canada's health-care program for refugees, refugee claimants, and certain other protected persons who are not eligible for provincial or territorial health insurance. Between 2012 and 2016 the IFHP endured extensive cuts. Despite its full restoration in
() Y.Y Brandon Chen, Vanessa Gruben, and Jamie Chai Yun Liew, 2018. This openaccess work is licensed under a Creative Commons Attribution-NonCommercial 4.o International Licence, which permits use, reproduction, and distribution in any medium for non-commercial purposes, provided the original authorship is credited and the original publication in Refuge: Canada's Journal on Refugees is cited.
Cette œuvre en libre accès fait l'objet d'une licence Creative Commons Attribution-NonCommercial 4.o International License, laquelle autorise l'utilisation, la reproduction et la distribution de l'ouvre sur tout support à des fins non commerciales, pourvu que l'auteur ou les auteurs originaux soient mentionnés et que la publication originale dans Refuge: revue canadienne sur les réfugiés soit citée. 
2016, these cuts have left an indelible mark on the system; many eligible persons are still not able to access and receive the health care they need.

When the IFHP was reinstated in 2016, the Canadian federal government contended that the program would "help ... to protect the health and safety of [IFHP] beneficiaries and Canadians." 2 This article presents findings from an exploratory study into how the restored IFHP is meeting its stated objective. It begins with an overview of the changes made to the IFHP between 2012 and 2016 to set the stage for our study. This policy overview is followed by a description of our research methods and findings. Results from interviews conducted with refugee service providers in the City of Ottawa suggest a continued misunderstanding among eligible persons and service providers alike concerning health-care entitlement under the IFHP, which adversely affects people's access to necessary services. These findings point to the need for further research into the performance of the IFHP, as well as additional policy measures beyond mere reinstatement of the program to safeguard the health and safety of refugees and refugee claimants.

\section{Changes to the IFHP since 2012}

In 2012 the federal government passed two orders-in-council changing who is eligible to receive medical benefits under the IFHP and reducing the level of coverage to certain individuals. ${ }^{3}$ These changes were supposedly designed to contain public spending, ensure fairness for Canadians, and discourage foreign nationals from filing "unfounded" refugee claims only to take advantage of Canada's public health-care system. ${ }^{4}$ However, they were widely condemned by the public and notably by twenty-one national health-care organizations. ${ }^{5}$

Under the IFHP that was in place before 30 June 2012, all refugee claimants received basic health-care coverage, which consisted of hospital services; services from doctors, nurses, and other health-care professionals, including prenatal and postnatal care; and laboratory, diagnostic, and ambulance services. All resettled refugees and refugee claimants were also entitled to supplemental coverage, which provided, among other things, limited vision and dental care, homeand long-term care, certain mental health services, physiotherapy, medical supplies and equipment, and prescription drug coverage. ${ }^{6}$ Resettled refugees typically would receive the IFHP coverage during the first year of their arrival in Canada. In contrast, refugee claimants were covered by the IFHP from the day they submitted their refugee application until they either obtained protection and permanent residency-at which point they would become eligible for provincial health care-or were set to be removed from the country in the event that their claims were unsuccessful. ${ }^{7}$
On 30 June 2012 the IFHP was changed to provide four categories of health-care coverage: (1) expanded health-care coverage; (2) health-care coverage; (3) public health or public safety coverage; and (4) detainee coverage. ${ }^{8}$

The first category provided the highest level of health-care coverage and was available only to government-assisted refugees and those privately sponsored refugees who received resettlement assistance. Much like the health-care coverage that was previously available to all refugees and refugee claimants, the "expanded health-care coverage" under the 2012 IFHP included coverage of a broad range of medical, diagnostic, and hospital services akin to those normally covered by provincial health insurance programs, as well as supplemental services and products. The cost of language translation in limited health-care settings was also covered. ${ }^{9}$

The second category, "health care coverage," provided help to refugee claimants who were not from certain designated countries of origin believed unlikely to produce "genuine refugees," from the time that they were declared eligible to submit a refugee claim-which could take several weeksuntil they were deemed a refugee or as long as an appeal or judicial review of their claim was pending. Resettled refugees who did not receive resettlement assistance from government and individuals who received a positive pre-removal risk assessment, hence a protected person, also fell into this category. ${ }^{10}$ Individuals in this category received hospital care, medical services, and diagnostic tests that were considered urgent or essential. Elective surgery, rehabilitation, and longterm care, as well as services provided by health professionals other than doctors and nurses, such as psychologists and midwives, were not covered. Medication and vaccines were also not covered, save for those needed for the prevention or treatment of a disease posing a risk to public health or public safety (i.e., a communicable disease or a psychiatric condition where a person could pose a danger to others). ${ }^{11}$

When refugee claimants were unsuccessful in obtaining refugee protection, they would receive the "public health or public safety coverage" until the date set for their removal from Canada. Beyond that date, they would receive no public health care coverage at all. This third category under the 2012 IFHP also included refused refugee claimants whose removal from Canada was suspended, and refugee claimants from a designated country of origin even when the outcome of their refugee applications was still pending. The scope of health-care coverage under this category was quite narrow. No health-care services or medications were provided except for treating diseases or conditions posing a risk to public health or public safety. ${ }^{12}$ Consequently, pregnant women belonging to this category no longer had publicly funded maternity care, and persons with mental illnesses would 
receive treatment only if they were considered a threat to the general public but not if they manifested suicidal ideations. ${ }^{13}$

The fourth category covered persons in immigration detention. It provided medical, hospital, and diagnostic services as well as medications and other medical products when such services and products were deemed necessary by a medical professional. ${ }^{14}$

Outside of these four categories, several groups of migrants found themselves without any health-care coverage whatsoever under the 2012 IFHP. They included individuals who submitted a refugee claim but were waiting for their eligibility determination; persons who submitted a pre-removal risk assessment and were waiting for a decision; persons who withdrew or abandoned their refugee claim or those found ineligible for a refugee claim; and refused refugee claimants who received a removal order but did not show up for removal. The first two of these groups were entitled to the IFHP prior to the 2012 cuts, whereas the latter two were not covered by the previous version of the program, either. ${ }^{15}$

Broadly speaking, all IFHP beneficiaries except government-assisted resettled refugees, victims of human trafficking, and immigration detainees lost some health-care coverage under the 2012 scheme. As such, the 2012 IFHP harmed an already vulnerable population who have unique healthcare needs. ${ }^{16}$ Many refugee claimants and protected persons were "simply unable to afford" required health care without public coverage. ${ }^{17}$ For a significant portion of them, vital services including immunizations for children, maternity care, and prevention and early diagnosis of chronic conditions became out of reach. ${ }^{18}$ As well, the elimination of supplemental benefits barred some from accessing essential medications for chronic illnesses such as diabetes, hypertension, and asthma.19 Evidence suggests that these cuts, instead of saving costs as purported by the federal government, likely downloaded costs to provinces and health-care institutions. ${ }^{20}$

Even before 2012, health-care professionals were already known to deny services to refugees because of unfamiliarity with the IFHP and frustration with its reimbursement process. ${ }^{21}$ The added complexity of the new IFHP exacerbated the level of confusion, ${ }^{22}$ leading to "an increase in the number of private practices and walk-in clinics [to refuse serving] anyone covered under the IFHP." ${ }^{23}$ The cuts also caused misunderstanding amongst refugees, refugee claimants, protected persons, and their advocates; many were unaware of whether they were eligible for IFHP and how to navigate the system. ${ }^{24}$

In 2014 Justice Mactavish of the Federal Court, in finding the 2012 IFHP violated the Canadian Charter of Rights and Freedoms, confirmed there was "considerable confusion on the part of health care providers in processing the health care claims of refugee claimants in the wake of the 2012 changes to the IFHP with the result that health care [was] denied to patients who were in fact eligible." 25 Further, "Doctors have demanded that patients pay the cost of medical treatment 'up front" and "some doctors have found the new system too confusing, and are now simply refusing to see any IFHP patients." ${ }^{26}$

The IFHP was fully restored to its pre-2012 form in April 2016. However, there is very little information on how well the reinstated IFHP is meeting its intended objective of protecting the health and safety of its beneficiaries. It is also unclear whether some of the program's shortcomings that predated the 2012 cuts have resurfaced. This study is a preliminary attempt to explore how the IFHP's reinstatement has affected refugee health care since. Specifically, this study aims to (1) examine practitioners' experience with providing, and assisting clients with receiving, health-care services under the restored IFHP; and (2) identify mechanisms to support practitioners so they can better serve IFHP patients.

\section{Research Method}

Eleven semi-structured qualitative interviews were conducted in the winter of 2017 with service providers in Ottawa who work with refugees or refugee claimants in health-related contexts. Interviewees were recruited through purposeful sampling. ${ }^{27} \mathrm{~A}$ list of thirty-seven key informants consisting of relevant health -care practitioners and administrators, refugee and settlement services providers, and IFHP administrators was compiled upon consultation with a doctor and a health navigator who are acquainted with refugee health-care provision in Ottawa. Upon receiving our invitation, eleven of the key informants agreed to take part in the study. They included one primary care physician, two nurse practitioners, one social worker, three mental health counsellors, two health-care administrators, and two settlement agency workers. Despite repeated invitations, no informants from walk-in clinics, optometric clinics, dental office, or the IFHP administrator (Medavie Blue Cross) agreed to be interviewed.

Interviews with participants averaged sixty minutes and explored participants' experiences with the IFHP prior to the 2012 policy change, during the years of cuts and after the 2016 reinstatement. Content analysis of interview transcripts was conducted to identify common themes. For the purpose of member checking, approximately one month after the interviews, research participants were invited to attend a presentation to review and respond to our findings. Additional information about participants' experience with the IFHP was also solicited at this presentation to complement interview data.

\section{Results}

Five themes emerged from the interviews: (1) service provision challenges during the years of IFHP cuts; (2) support for IFHP restoration; (3) entitlement gaps in the current 
IFHP; (4) ongoing confusion about the IFHP; and (5) administrative barriers deterring health professionals from IFHP participation.

\section{Service Provision Challenges during the Years of Curtailment}

When asked about their experience with the IFHP between 2012 and 2016, a large majority of participants spoke of confusion and frustration as a result of the cuts. Settlementworker and social-worker participants reported encountering health-care providers who mistakenly turned away IFHP-entitled clients, as well as providers who stopped seeing refugee patients altogether. One health-care administrator recounted an incident where the scheduled cataract surgery of an eligible refugee claimant whose vision was decreasing in both eyes did not proceed because the eye-care specialist decided to no longer accept IFHP patients.

Both health-care practitioners and administrators complained about the complexity and uncertainty of the 2012 IFHP forcing them to take time away from service provision to determine refugee patients' health-care coverage. In the event of non-coverage, some health-care providers lamented the need to absorb treatment costs to maintain compliance with practice guidelines and medical ethics.

\section{Support for IFHP Reinstatement}

The reinstatement of IFHP was welcomed by all interviewees, with many reporting improved health-care access for refugees and refugee claimants. One settlement worker felt relieved when her clients finally received eyeglasses after years of forgoing vision care for lack of coverage. Two interviewees reported knowing new practitioners who came forward to take on refugee patients following the IFHP's restoration.

Along with restoring the IFHP's scope of coverage to the pre-2012 level, the policy change in 2016 removed the need for refugee claimants to renew their IFHP certificates annually, ensuring the validity of such certificates throughout the asylum application process. Several interviewees praised this policy change, noting that in the past, failure and/or inability to renew IFHP certificates had been a common impediment to refugee claimants' health-care access.

Health-care practitioners further observed the IFHP reinstatement improving their work. They noted greater ability to refer IFHP beneficiaries to specialists. They also welcomed the ability to focus more energy on treating patients. As one nurse practitioner explained, "I don't have to do as much system-level personal advocacy for my patients."

\section{Gaps in IFHP Entitlement}

Despite support for the program's reinstatement, interviewees identified several issues with the current IFHP that continue to hamper refugees' and refugee claimants' healthcare access. Notably, there are gaps in what and whom the IFHP covers. A regular complaint of interviewees was the inadequacy of medical interpretation for IFHP beneficiaries. The IFHP covers only the cost of interpretation and translation if it is associated with mental health care and, specifically for resettled refugees, post-arrival health assessment. Interpretation for other health-related services are not covered. This, as one nurse practitioner pointed out, could deter patients' service access notwithstanding their legal entitlement. She explained language barriers affect one's ability to not only understand important medical information such as how to take medications properly, but also to book an appointment in the first place. She observed that many of her clients did not get their eyes checked until their children were old enough to understand eye-care practitioners' instructions, but noted that "some eye clinics aren't comfortable having a parent that can't really consent."

Further, interviewees cautioned that the current rate of reimbursement to interpreters, at $\$ 28.95$ per hour, falls well below the market standard. As another nurse practitioner concluded, "It is not a meaningful coverage." This was underscored by an administrator of a community health centre, whose clients included a group of deaf refugees. She noted that for each doctor's visit, the cost of interpretation for these clients amounted to $\$ 300$, much of which had to be assumed by the health centre.

Coverage for mental health services was raised as another weakness. The IFHP covers certain counselling provided by clinical psychologists, registered psychotherapists, and counselling therapists. For beneficiaries who do not have provincial health care, the program also pays for mental health service delivered by psychiatrists and family physicians. ${ }^{28}$ At the time of our study, counselling services provided by registered social workers and nurses were not covered. Multiple interviewees argued that this should be changed to alleviate long waiting lists.

One health-care administrator also noted children born in Canada to refugee parents do not qualify for IFHP. Although they are supposed to be included in provincial health-care plans, many of these plans lack supplemental benefits like prescription drug coverage. If the parents of these children are government-assisted or privately sponsored refugees, they are also not eligible for drug coverage that some provincial social assistance programs offer, because their parents are prohibited from receiving welfare for at least one year. The interviewee asked, "If the child is born with any kind of illnesses ... who is going to pay for the prescription for that child? Mother? Let's say it's a single mother with [income support from the federal government], it's not enough.... The child falls through the crack. They cannot get [provincial 
coverage], they don't have IFH, so who's paying for that? ... That's a huge gap."

\section{Confusion about IFHP}

Clear and accessible information about the IFHP appears to be lacking for patients and service providers alike. One nurse practitioner described the IFHP as being mired in "a legacy of confusion," suggesting the instability and complexity of the program during the years of cuts continue to cloud people's understanding.

Several interviewees admitted to being unsure about the eligibility criteria and the scope of service coverage of the reinstated IFHP. Providers' unfamiliarity with the IFHP, in turn, could become a barrier to access. Interviewees noted that, despite the program's reinstatement, some providers continued to deny services to IFHP patients in the mistaken belief about their health care coverage. Our family physician participant reported having her IFHP patients turned away by a local pharmacy. Another nurse practitioner shared that his client encountered problems at a private laboratory that assumed a test was not covered because the client had IFHP

Interviewees emphasized the need for better education for service providers. They stressed that most health-care providers are open to learning more about the program, but the available information is not user friendly or accessible. Of particular confusion are the benefit grids, which detail the services and treatments covered by the IFHP. Interviewees complained that the grids were complicated. One nurse practitioner confessed, "I'm honestly still not clear if an eye exam is covered for a child or not. Sometimes it seems to be and sometimes it's not, and I don't understand why."

The confusion is reportedly compounded by service providers' inability to seek clarification from Medavie Blue Cross (Medavie), the insurance company contracted by government to administer the IFHP. While Medavie has a telephone number that service providers can call to ask questions, the company responds only to inquiries from health professionals already registered in the IFHP. One settlement worker observed, "For us ... we don't have access to Medavie. We have to encourage the medical community to check with Medavie [for information] because we can't talk to them ourselves.... There is very little we can do to clarify anything [for our clients]."

\section{Administrative Barriers to Service Provision}

Multiple interviewees described the IFHP as "bureaucratic," which they believed contributed to some practitioners' reluctance to partake in the program. They pointed to the registration, preapproval, and reimbursement processes as particularly burdensome. If health-care providers wish to be reimbursed for services rendered to IFHP beneficiaries, they must first register with Medavie. This, according to our family physician participant, could discourage practitioners' involvement in the IFHP, especially when many already found the program complex. A nurse practitioner likewise considered registration a barrier "for busy providers" who may come across IFHP patients only occasionally.

Once registered, health-care providers are further required by Medavie to obtain preapproval before certain services or products are delivered. This preapproval process can sometimes be time consuming. One health-care administrator recounted having to wait more than three months to obtain approval for counselling support for a client's immigration-related trauma.

Interviewees pointed to the IFHP's reimbursement process as another source of frustration. Some complained the procedure for submitting reimbursement claims was "complicated" and involved "too much paperwork." Moreover, requests for reimbursement were sometimes denied without adequate explanation from Medavie. As one health centre manager lamented, "Twenty to 25 per cent of the claims that we billed come back denied" with no explanation. The same interviewee noted that, even when the claims were accepted, it could take thirty to ninety days to receive payments and as a result, some service providers stopped caring for IFHP patients. By contrast, our family physician participant reported having positive experiences, describing the billing process as "easy" and faster than its counterpart under Ontario's health insurance plans. These diverging experiences require further study and may suggest inconsistency in the current IFHP reimbursement practice.

\section{Discussion \\ Evaluation of the IFHP}

This study found that while there have been significant improvements to refugees' and refugee claimants' access to health care following the restoration of IFHP, there are also ongoing problems with the program. First, there are several gaps in coverage. Medical interpretation and mental health counselling receive inadequate coverage. In particular, medical interpreters and translators receive insufficient compensation. Also, for some Canadian-born children of IFHP beneficiaries, despite qualifying for provincial health care, their ineligibility for the IFHP threatens access to supplemental services and products that may not be covered by provincial health insurance plans, such as dental care, vision care, and medication.

These coverage gaps are not unique to the IFHP. Similar criticisms about deficient coverage of medical interpretation and mental health services have commonly been laid against provincial health-care programs. ${ }^{29}$ However, inadequate public coverage of these services can have particularly serious health ramifications for refugees and refugee claimants. 
Research consistently shows that refugees and refugee claimants encounter stressors both before and after migration that compromise their mental health. ${ }^{30}$ Poor English or French proficiency is also a well-documented barrier to refugees' health-care access. ${ }^{31}$ Therefore, insufficient coverage of these services under the IFHP presents a very real risk of further undermining refugees' and refugee claimants' well-being and impeding their search for necessary care.

Likewise, inadequate coverage for supplemental services is a problem that many Canadians, not just Canadian-born children of IFHP beneficiaries, struggle with. ${ }^{32}$ Nevertheless, important considerations make the exclusion of these Canadian-born children from the IFHP especially concerning. Statistics show that newcomers to Canada, including refugees, are more likely than their Canadian-born counterparts to be unemployed and to live in poverty. ${ }^{33}$ Thus, for children of refugees, being left out of the IFHP represents a significant financial barrier to accessing supplemental services. The access challenge is all the more acute for Canadian-born children of resettled refugees, who are prohibited from receiving provincial social assistance and the attendant supplemental health benefits during their first year in Canada. ${ }^{34}$ Furthermore, some evidence suggests the health-care coverage gap facing Canadian-born children of refugees and refugee claimants may be broader than the lack of entitlement to supplemental services and products. A study published in 2014 revealed that in parts of Atlantic Canada, Canadian-born children of refugee claimants were being excluded from provincial health-care programs altogether as a result of their parents' non-resident status in the respective provinces. ${ }^{35}$ Conversations of our research team with refugee service providers in these provinces suggest that the situation persists. In these situations, Canadian-born children fall through the crack between the IFHP and provincial health care, leaving them with no public health-care coverage at all. More research is urgently needed to flesh out the implications of IFHP ineligibility for Canadian-born children of refugees and refugee claimants.

Beyond entitlement gaps, our findings indicate IFHP beneficiaries' access to health care may be hampered by how the program's reinstatement has been communicated and by administrative hurdles embedded in the program. At least for practitioners working in the city of Ottawa, a legacy of confusion persists. Most of the confusion arises about whom and what the current IFHP covers. There is a concern that service providers like pharmacists and some specialists continue to mistakenly deny care to eligible recipients. There is further confusion associated with navigating the benefit grids, which are seen as complicated and at the same time devoid of specificity.
Additionally, the administration of the IFHP is perceived as burdensome. The registration process for prospective health-care providers is considered too demanding by some. Further, the reimbursement process appears to be uneven. While some reported timely reimbursement, others complained of long delays. Some of the IFHP billing codes are reportedly vague, and denial of coverage is not clearly explained. These administrative challenges are aggravated by reportedly poor communication on the part of Medavie.

These complaints about confusion surrounding the IFHP and its administration echo other evaluations of the program conducted before and during the years of cuts. ${ }^{36}$ The persistence of these issues shows that the reinstatement of the IFHP by itself is likely insufficient to achieve the stated objective of protecting beneficiaries' health and safety. Research in and outside Canada consistently observes that laws and policies that ostensibly stipulate robust health-care entitlement do not singlehandedly guarantee migrants' access to healthcare services. ${ }^{37}$ For example, during the years of the IFHP cuts, many refugee claimants in Quebec reported experiencing significant difficulties accessing health care in spite of the province having introduced a temporary program soon after 2012 to help them maintain much of their health-care entitlement. $^{38}$

If misinformation about the program and administrative hurdles discourage service providers from taking on IFHP beneficiaries as clients, they threaten to limit the range of health care that is available and accessible to refugees and refugee claimants who are legally entitled to receive such care. Moreover, literature shows patients commonly modify their perceived health-care entitlement on the basis of information received from service providers, assuming service providers would know better.39 As such, when incorrect information about IFHP eligibility and coverage harboured by service providers is communicated to patients, this could cause patients to refrain from seeking health-care services in the future to which they are in fact entitled. Even when patients do question the accuracy of service providers' understanding of their health-care eligibility, research finds these patients sometimes interpret providers' misinformation as an act of discrimination, which also deters them from seeking further help. ${ }^{40}$

\section{Recommendations for Improvement}

The small sample size of this study reflects its exploratory nature. At a minimum, the consistency between our results and those from previous studies about the IFHP points to the need for the government to take additional measures beyond simply reinstating its pre-2012 policies in order to truly ensure the health and safety of refugees and 
refugee claimants. Accordingly, several recommendations are warranted.

First, and building on similar calls from others who have examined the subject, ${ }^{41}$ more informational materials about the IFHP must be made accessible to all stakeholders, including health-care providers, refugees, and their settlement support workers. Such materials should explain whom and what the IFHP covers and the registration and reimbursement processes. Further, better communication with Medavie is greatly needed. Non-health providers working with refugees and refugee claimants should be able to speak to Medavie representatives to have questions answered. This opportunity could lessen health-care providers' misinformation about eligibility.

Second, several changes are needed to improve the administration of the IFHP. If the program runs smoothly and efficiently, more practitioners may be expected to register as IFHP providers, thus improving service access for refugees and refugee claimants. Key administrative changes should include streamlining the registration, preapproval, and reimbursement processes, and making the benefit grids more user-friendly. Notably, since the completion of our interviews, Medavie has introduced a new web portal that enables service providers to more easily submit their reimbursement claims electronically. ${ }^{42}$ Future research should assess how this new portal is meeting the needs of service providers and whether it alleviates some of the administrative challenges identified in this study.

Third, on the basis of what we heard from interviewees, benefit coverage of the IFHP should be expanded to meet the unique needs of refugees and refugee claimants. To the extent that IFHP beneficiaries' access to mental health counselling is hindered by long wait times, a potential solution is to extend IFHP coverage to counselling done by allied health professionals. We applaud the government's decision in May 2018 to start covering counselling delivered by licensed social workers. ${ }^{43}$ The effect of this change on IFHP beneficiaries' access to mental health care must be studied, and so must the need to further broaden IFHP coverage to include nurse-performed counselling. Greater coverage and a higher rate of compensation for medical interpretation is also needed. The possibility of including Canadian-born children of beneficiaries in the IFHP should be explored, particularly if it is confirmed that some of these children are being left completely without public health care coverage.

\section{Conclusion and Next Steps}

This exploratory study sought to shed light on the performance of the reinstated IFHP in meeting the health-care needs of refugees and refugee claimants. Refugee service providers reported that the currentIFHP, despite significant improvements from the years of cuts, falls short in several respects in facilitating refugees' and refugee claimants' access to high-quality health care. However, the scope and design of the present study limits our ability to provide a conclusive assessment. To more fully understand the gaps articulated by our research participants and the need to reform the current program, further research is required. Foremost, it will be critical to hear directly from refugees and refugee claimants. Additionally, the perspectives of a broader range of service providers, including dentists, eye-care providers, and pharmacists should be gathered. Importantly, future studies should also explore potential challenges facing service providers who do not work with IFHP beneficiaries but wish to do so. It is possible that interviewing practitioners who are already serving IFHP beneficiaries, as we did, will lead to under-reporting of the confusion around the IFHP, given providers' greater familiarity with the program. Moreover, efforts must be made to canvass the experiences of serviceseeking and provision outside Ottawa to determine whether the challenges identified in this study arise on a national scale.

\section{Notes}

1 The authors would like to thank Harmehak Somal for her excellent research assistance as well as the students of "CML 4104B: International Migration \& Health" for their important contribution to this project.

2 Government of Canada, "Interim Federal Health Program Policy," last modified 23 March 2018, https://www.canada.ca/en/immigration-refugees-citizenship/corporate/ mandate/policies-operational-instructions-agreements/ interim-federal-health-program-policy.html.

3 Order Respecting the Interim Federal Health Program, SI/2012-26, (2012) Canada Gazette II, 146:9; Order Amending the Order Respecting the Interim Federal Health Program, sI/2012-49, (2012) Canada Gazette II, 146:15.

4 Government of Canada, "Reform of the Interim Federal Health Program Ensures Fairness, Protects Public Health and Safety," last modified 25 April 2012, https://www.canada.ca/en/news/archive/2012/04/reform-interim-federalhealth-program-ensures-fairness-protects-public-healthsafety.html.

5 Rebecca Warmington and Dolly Lin, "Healthcare Is Political: Case Example of Physician Advocacy in Response to the Cuts to Refugees' and Claimants' Healthcare Coverage under the Interim Federal Health Program," University of Ottawa Journal of Medicine 4, no. 1 (May 2014): 45-8, https://doi.org/10.18192/uojm.v4i1.1040.

6 Citizenship and Immigration Canada (hereafter CIC), IR 3: Medical (Ottawa: CIC, 2010) 5.

7 CIC, IR 3, 5 . 
8 CIC, "Information Sheet for Interim Federal Health Program Beneficiaries" (Ottawa: cIC, 2012).

9 CIC, "Information Sheet."

10 Order Respecting the Interim Federal Health Program, s 4.

11 CIC, "Information Sheet."

12 CIC, "Information Sheet."

13 CIC, Interim Federal Health Program Reform: Examples of Coverage for Selected Conditions (Ottawa: CIC, 2012).

14 CIC, "Information Sheet."

15 CIC, IR 3.

16 Steve Barnes, The Real Cost of Cutting Refugee Health Benefits: A Health Equity Impact Assessment (Toronto: Wellesley Institute, 2012); Immigration Matters in Canada Coalition, "Federal Cuts Put Refugee Health Care in Danger," Canadian Centre for Policy Alternatives, https:// www.policyalternatives.ca/publications/commentary/ federal-cuts-put-refugee-health-care-danger.

17 Helen P. Harris and Daniyal Zuberi, "Harming Refugee and Canadian Health: The Negative Consequences of Recent Reforms to Canada's Interim Federal Health Program," Journal of International Migration and Integration 16, no. 4 (November 2014): 1041-55, https://doi.org/10.1007/ S12134-014-0385-X.

18 Harris and Zuberi, "Harming Refugee and Canadian Health"; Warmington and Lin, "Healthcare Is Political"; Barnes, Real Cost.

19 Canadian Council for Refugees, "Refugee Health Care: Impacts of Recent Cuts," 2013, http://ccrweb.ca/files/ifhreporten.pdf; L. Eggertson, "Doctors Promise Protests along with Court Challenge to Refugee Health Cuts," CMAJ 185, no. 7 (April 2013): E275-E276, https://doi.org/10.1503/ cmaj.109-4430; Harris and Zuberi, "Harming Refugee and Canadian Health."

20 Andrea Evans, Alexander Caudarella, Savithiri Ratnapalan, and Kevin Chan, "The Cost and Impact of the Interim Federal Health Program Cuts on Child Refugees in Canada," PLOS ONE 9, no. 5 (May 2014): e106198, https://doi. org/10.1371/journal.pone.0096902; Francis Bakewell, Sarah Addleman, Garth Dickinson, and Venkatesh Thiruganasambandamoorthy, "Use of the Emergency Department by Refugees under the Interim Federal Health Program: A Health Records Review," PLOS ONE 13, no. 5 (May 2018): e0197282, https://doi.org/10.1371/journal.pone.0197282.

21 Baukje Miedema, Ryan Hamilton, and Julie Easley, "Climbing the Walls: Structural Barriers to Accessing Primary Care for Refugee Newcomers in Canada," Canadian Family Physician 54, no. 3 (March 2008): 335-6; Joshua Wales, "Interim Federal Health: A Public Health Perspective," McMaster University Medical Journal 7, no. 1 (May 2010): 50-2; Marie Mckeary and Bruce Newbold, "Barriers to Care: The Challenges for Canadian Refugees and Their Health Care Providers," Journal of Refugee Studies 23, no. 4 (December 2010): 523-45, https://doi.org/10.1093/jrs/ feqo38.
22 Mónica Ruiz-Casares, Janet Cleveland, Youssef Oulhote, Catherine Dunkley-Hickin, and Cécile Rousseau, "Knowledge of Healthcare Coverage for Refugee Claimants: Results from a Survey of Health Service Providers in Montreal," PLOS ONE 11, no. 1 (January 2016): e0146798, https:// doi.org/10.1371/journal.pone.0146798; Valentina Antonipillai, Andrea Baumann, Andrea Hunter, Olive Wahoush, and Timothy o'shea, "Impacts of the Interim Federal Health Program Reforms: A Stakeholder Analysis of Barriers to Health Care Access and Provision for Refugees," Canadian Journal of Public Health 108, no. 4 (2017): e435-e441, http:// dx.doi.org/10.17269/cjph.108.5553.

23 Harris and Zuberi, "Harming Refugee and Canadian Health," 1048.

24 Harris and Zuberi, "Harming Refugee and Canadian Health," 1048; Eggertson, "Doctors Promise Protest."

25 Canadian Doctors for Refugee Care v Canada (AG), 2014 FC 651, para 134.

26 Canadian Doctors for Refugee Care v Canada (AG), 2014 FC 651, paras 135-6.

27 Martin N. Marshall, "Sampling for Qualitative Research," Family Practice 13, no. 6 (January 1996): 522-6, https://doi. org/10.1093/fampra/13.6.522.

28 Medavie Blue Cross, "IFHP Benefit Grid: Supplemental Coverage," last modified 6 July 2016, http://pub.medavie. bluecross.ca/pub/ooo1/PublicDocuments/IFHP\%2oBenefit\%20Grid\%20-\%20Supplemental\%2oFinal.pdf.

29 Keith Doucette, "It's Time to Bolster Canada's Chronically Under-Funded Mental Health Care System, Advocates Assert," Times-Transcript, 29 August 2016; Nishi Kumar, Nazeefah Laher, Anjum Sultana, and Anjana Aery, "The Right to Language Accessibility in Ontario's Health Care System," last modified 21 June 2017, http://www.wellesleyinstitute.com/health/the-right-to-language-accessibilityin-ontarios-health-care-system/.

30 Ruth Marie Wilson, Rabea Murtaza, and Yogendra B. Shakya, "Pre-Migration and Post-Migration Determinants of Mental Health for Newly Arrived Refugees in Toronto," Canadian Issues (Summer 2010): 45-9; Laurence J. Kirmayer, Lavanya Narasiah, Marie Munoz, Meb Rashid, Andrew G. Ryder, Jaswant Guzder, Ghayda Hassan et al., "Common Mental Health Problems in Immigrants and Refugees: General Approach in Primary Care," CMAJ 182, no. 12 (September 2011): E959-67, https://doi.org/10.1503/ cmaj.090292.

31 Marie McKeary and Bruce Newbold, "Barriers to Care: The Challenges for Canadian Refugees and Their Health Care Providers," Journal of Refugee Studies 23, no. 4 (December 2010): 523-45, https://doi.org/10.1093/jrs/feqo38.

32 Steven G. Morgan and Katherine Boothe, "Universal Prescription Drug Coverage: Long-Promised Yet Undelivered," Healthcare Management Forum 29, no. 6 (November 2016): 247-54, doi:10.1177/o840470416658907; Carlos Quiñonez and Rafael Figueiredo, "Sorry Doctor, I Can't Afford the Root Canal, I Have a Job: Canadian Dental Care Policy and 
the Working Poor," Canadian Journal of Public Health 101, no. 6 (November/December 2010): 481-5, http://dx.doi. org/10.17269/cjph.101.1964.

33 Government of Canada, "Towards a Poverty Reduction Strategy: A Backgrounder on Poverty in Canada," last modified 27 February 2017, https://www.canada.ca/en/ employment-social-development/programs/povertyreduction/backgrounder.html.

34 "Dispelling an Urban Myth: Refugees to Canada Do Not Receive More Federal Funding Than Senior Citizens," Toronto Star, 12 December 2015.

35 Evangelia Tastsoglou, Catherine Baillie Abidi, Susan M. Brigham, and Elizabeth A. Lange, "(En)Gendering Vulnerability: Immigrant Service Providers' Perceptions of Needs, Policies, and Practices Related to Gender and Women Refugee Claimants in Atlantic Canada," Refuge 30, no. 2 (2014): 67-78.

36 Antonipillai et al., "Impacts of IFHP Reforms"; Ruiz-Casares et al., "Knowledge of Healthcare Coverage"; N. Rink, F. Muttalib, G. Morantz, L. Chase, J. Cleveland, C. Rousseau, and P. Li, "The Gap between Coverage and Care: What Can Canadian Paediatricians Do about Access to Health Services for Refugee Claimant Children?" Paediatrics \& Child Health 22, no. 8 (November 2017): 430-7, https://doi. org/10.1093/pch/pxx115.

37 Charles Watters, “Towards a New Paradigm in Migrant Health Research: Integrating Entitlement, Access and Appropriateness," International Journal of Migration, Health and Social Care 7, no. 3 (2011): 148-59, https://doi. org/10.1108/17479891111196168; Anita J. Gagnon, “The Responsiveness of the Canadian Health Care System towards Newcomers," in Changing Health Care in Canada:
Romanow Papers, Volume 2, ed. Pierre-Gerlier Forest, Gregory Marchildon, and Tom McIntosh, 349-88 (Toronto: University of Toronto Press, 2004).

38 Liana E. Chase, Janet Cleveland, Jesse Beatson, and Cécile Rousseau, "The Gap between Entitlement and Access to Healthcare: An Analysis of 'Candidacy' in the Help-Seeking Trajectories of Asylum Seekers in Montreal," Social Science \& Medicine 182 (June 2017): 52-9, https://doi.org/10.1016/j. socscimed.2017.03.038.

39 Chase et al., "Gap between Entitlement and Access."

40 Chase et al., "Gap between Entitlement and Access."

41 Ruiz-Casares et al., "Knowledge of Healthcare Coverage."

42 "Immigration, Refugees and Citizenship Canada (IRCC)," https://providerifhpen.medavie.bluecross.ca.

43 Medavie Blue Cross, "IfHP Benefit Grid: Supplemental Coverage," last modified 30 May 2018, http://pub.medavie. bluecross.ca/pub/ooo1/PublicDocuments/CIC-03oE\%2O IFHP\%2OBenefit\%2OGrid\%20-\%20Supplemental\%2OEN. pdf.

Y.Y. Brandon Chen is an assistant professor at the University of Ottawa Faculty of Law. The author may be contacted at yy.chen@uottawa.ca.

Vanessa Gruben is an associate professor at the University of Ottawa Faculty of Law. The author may be contacted at vanessa.gruben@uottawa.ca.

Jamie Chai Yun Liew is an associate professor at the University of Ottawa Faculty of Law. The author may be contacted at Jamie.Liew@uottawa.ca. 